\title{
Should children with esophageal varices receive beta-blockers for the primary prevention of variceal hemorrhage?
}

\author{
Simon C Ling MB ChB
}

\begin{abstract}
SC Ling. Should children with esophageal varices receive betablockers for the primary prevention of variceal hemorrhage? Can J Gastroenterol 2005;19(11):661-666.

Esophageal variceal hemorrhage occurs in up to $10 \%$ of children with portal hypertension annually, and may be fatal. In contrast to the strong evidence in adults that nonselective beta-adrenergic antagonism reduces the risk of variceal bleeding by approximately $50 \%$, few pediatric data are available. The use of beta-blockers for primary prophylaxis has been reported in children, but not tested in a randomized controlled trial. The risks and benefits in children remain unquantified and may differ from adults in light of the different cardiovascular response to hypovolemia in young children. The circumstances of the individual patient must, therefore, be carefully considered before betablockers are prescribed to children with esophageal varices.
\end{abstract}

Key Words: Adrenergic beta-antagonists; Children; Esophageal and gastric varices; Hypertension, portal; Propranolol
Les enfants présentant des varices œesophagiennes devraient-ils recevoir des bêta-bloquants en prévention primaire des hémorragies variqueuses?

\begin{abstract}
L'hémorragie œsophagienne variqueuse s'observe chez jusqu'à $10 \%$ des enfants qui souffrent d'hypertension portale chaque année et elle peut être fatale. Contrairement aux preuves solides enregistrées chez les adultes à l'effet que l'antagonisme bêta-adrénergique non sélectif réduit le risque d'hémorragie variqueuse d'environ $50 \%$, on dispose de peu de données à cet égard chez les enfants. L'utilisation des bêta-bloquants en prophylaxie primaire a été signalée chez les enfants, mais n'a pas été mise à l'épreuve dans le cadre d'essais contrôlés randomisés. Les risques et les avantages chez les enfants n'ont pas été mesurés et pourraient différer de ce qui s'observe chez les adultes, puisque la réponse cardiovasculaire à l'hypovolémie est différente chez les jeunes enfants. Les conditions propres à chaque patient doivent donc, par conséquent, être étudiées avec soin avant que l'on ne prescrive des bêta-bloquants à des enfants qui présentent des varices œesophagiennes.
\end{abstract}

$\mathrm{V}_{\mathrm{p}}$ ariceal hemorrhage is a life-threatening complication of portal hypertension that occurs commonly in children with chronic liver disease or portal vein obstruction (1-8). In children with biliary atresia, the incidence of variceal hemorrhage ranges from $17 \%$ to $29 \%$ over a five- to 10 -year period (3-5) and is $50 \%$ in children who survive more than 10 years without liver transplantation (6). Among 50 children with esophageal varices, primarily due to cirrhosis, who were prospectively followed and not offered active treatment to prevent variceal bleeding, $42 \%$ suffered upper gastrointestinal hemorrhage during a median 4.5 year follow-up period (2). For children with portal vein thrombosis, the available studies suggest that up to $50 \%$ suffer a major variceal hemorrhage by 16 years of age (1). The mortality rate from gastrointestinal bleeding ranges from $2.5 \%$ to $20 \%$ in children with portal hypertension $(2,4,7,8)$. Prevention is, therefore, an important goal.

Although the majority of North American pediatric hepatologists report a willingness to use beta-blockers for primary prophylaxis (9), this approach in children is controversial due to the lack of pediatric data and the wariness among pediatricians of extrapolating results of adult studies to children (10). The present review discusses the mechanism of action of betablockers in the context of the pathophysiology of portal hypertension, compares the evidence for pharmacological and endoscopic prophylaxis in both adults and children, and considers the additional factors that determine whether nonselective beta blockade is an appropriate intervention for children at risk of variceal hemorrhage.

\section{THE PATHOPHYSIOLOGY OF PORTAL HYPERTENSION AND THE MECHANISM OF ACTION OF NONSELECTIVE BETA-BLOCKERS}

In portal hypertension caused by cirrhotic liver disease, vascular resistance in the portal system is elevated by distorted hepatic architecture, intrahepatic small vessel thromboses and increased intrahepatic vascular tone arising from the actions of vasoactive substances on myofibroblasts, perisinusoidal activated stellate cells and vascular smooth muscle cells (11-16). Whereas the intrahepatic vascular bed is constricted, splanchnic arteriolar dilation exacerbates portal hypertension by increasing portal venous inflow (17-19).

Varices develop when the hepatic venous pressure gradient (HVPG), a measurement obtained by transjugular cannulation of the hepatic veins (20), is elevated above $10 \mathrm{mmHg}$ to $12 \mathrm{mmHg}$ (21). Recent evidence suggests that active angiogenesis may contribute to the development of varices in addition to the effect of increased pressure and flow within potential portosystemic anastamoses (22). Variceal bleeding occurs when increased vein diameter, decreased wall thickness and increased intraluminal pressure elevate variceal wall tension beyond the maximum tolerable threshold (19). Clinical predictors of variceal hemorrhage in adults include the severity of liver disease measured by the Child-Pugh score, the presence of ascites, the size and appearance of the varices at endoscopy, as well as the degree of elevation of HVPG (23).

Division of Gastroenterology, Hepatology and Nutrition, The Hospital for Sick Children, Toronto, Ontario

Correspondence: Dr Simon C Ling, The Hospital for Sick Children, 555 University Avenue, Toronto, Ontario M5G 1 X8.

Telephone 416-813-8757, fax 416-813-6531, e-mail simon.ling@sickkids.ca

Received for publication June 7, 2005. Accepted June 14, 2005 
TABLE 1

Studies reporting the use of therapies to prevent the first variceal hemorrhage in children

\begin{tabular}{|c|c|c|c|c|c|}
\hline & $\mathbf{n}$ & Study details & Controls & Follow-up & $\begin{array}{l}\text { Esophageal } \\
\text { variceal bleeding }(\%)\end{array}$ \\
\hline \multicolumn{6}{|l|}{ Beta-blockers } \\
\hline Shashidhar et al (45) & 17 & $\begin{array}{l}\text { Case series, four further children received secondary prophylaxis, } \\
\text { results provided reflect outcome in all } 21 \text { children. Two children had } \\
\text { prehepatic PHT. All-cause upper GI bleeding in seven children (33\%). }\end{array}$ & None & 3 years & 24 \\
\hline Ozsoylu et al (46) & 45 & Case series, all with biopsy-proven cirrhosis. & None & 5.5 years & 16 \\
\hline Erkan et al (47) & 13 & $\begin{array}{l}\text { Case series, three with prehepatic PHT. Additional seven patients } \\
\text { treated with combined beta-blocker and EIS, one with bleeding. }\end{array}$ & None & 5.2 years & 15 \\
\hline Sasaki et al (80) & 9 & $\begin{array}{l}\text { Case series, all with biliary atresia. Only early outcome reported, } \\
\text { appearance of varices improved or eradicated in six, not improved } \\
\text { in three after one to seven sessions of ligation with loop-ligator. }\end{array}$ & None & $7-14$ days & 0 \\
\hline Celinska-Cedro et al (78) & 31 & $\begin{array}{l}\text { Case series, } 50 \% \text { prehepatic PHT. One child had bleeding from } \\
\text { portal gastropathy. }\end{array}$ & None & 1.3 years & 0 \\
\hline \multicolumn{6}{|l|}{ EIS } \\
\hline Gonçalves et al (2) & 100 & $\begin{array}{l}\text { Randomized controlled trial, } 50 \text { children underwent EIS versus } \\
50 \text { controls, } 9 \% \text { with prehepatic PHT. Results for any cause of } \\
\text { upper GI bleeding, } 24 \% \text { EIS versus } 48 \% \text { controls, } P<0.05 \text {. }\end{array}$ & $\begin{array}{c}\mathrm{n}=50 \\
\text { no therapy }\end{array}$ & 4.5 years & $\begin{array}{c}6 \text { EIS versus } \\
42 \text { controls }(P<0.05)\end{array}$ \\
\hline
\end{tabular}

EIS Endoscopic injection sclerotherapy; GI Gastrointestinal; PHT Portal hypertension

Nonselective beta-blockers reduce the HVPG by reduction of cardiac output (mediated by beta-1-receptor antagonism), reduction of portal venous flow by unopposed alpha-receptormediated splanchnic vasoconstriction (following antagonism of beta-2-receptors) and by antagonism of the noradrenalineinduced constriction of intrahepatic myofibroblasts, activated stellate cells and vascular smooth muscle cells $(12,13,24-26)$.

\section{STUDIES OF BETA-BLOCKERS IN CHILDREN WITH PORTAL HYPERTENSION}

Following early reports of potential benefit more than 20 years ago $(27,28)$, nonselective beta-blockers were shown to be superior to placebo or no active treatment in the prevention of first variceal hemorrhage in several randomized controlled trials in cirrhotic adults (29-37). Meta-analyses of these studies confirm that beta-blockers reduce the incidence of variceal hemorrhage by approximately $50 \%$ (38-40).

However, in light of numerous examples of drugs whose efficacy, pharmacokinetics or adverse event profiles differ significantly between adults and children, care must be taken before extrapolating to children the evidence for efficacy of betablockers in cirrhotic adults $(41,42)$. Biliary atresia is the most common cause of advanced liver disease in children and largely accounts for the excess of biliary disease among cirrhotic children, whereas alcoholic liver disease accounted for the majority of the adults included in the randomized studies of beta-blocker prophylaxis. Although there is no difference in response to betablocker prophylaxis between alcoholic and other cirrhotic adults $(30-33,36,43)$, it is difficult to estimate whether a oneyear-old infant with biliary atresia will respond to beta-blockers similarly to a 60 -year-old adult with alcoholic cirrhosis. Pediatric data are, therefore, needed.

The ability of propranolol to reduce portal pressure was initially studied in 13 children with portal hypertension who received $2.1 \mathrm{mg} / \mathrm{kg} /$ day to $8.0 \mathrm{mg} / \mathrm{kg} /$ day of propranolol that induced an average decrease in heart rate of $25 \%$ of baseline (44). Four children with decompensated cirrhosis showed little or no response, and overall, the splenic pulp pressure (a proxy for portal venous pressure) decreased by a mean of only $13 \%$, from $387 \mathrm{mmH}_{2} \mathrm{O}$ to $337 \mathrm{mmH}_{2} \mathrm{O}$. This suggests a limited efficacy of propranolol in these children, although the value of this measurement in predicting variceal hemorrhage is untested.

Clinical experience with propranolol was reported in a retrospective uncontrolled study from Boston, USA, which included a mixed group of 21 children: 19 children had cirrhosis, two had extrahepatic portal vein obstruction, 17 children received primary prophylaxis and four received secondary prophylaxis (45). The propranolol dosage schedule aimed to reduce the heart rate by $25 \%$ (achieved in 17 children). Seven of 21 children (33\%) had upper gastrointestinal hemorrhage during a median follow-up period of three years. All adverse events (including rash, dizziness, bradycardia, hypotension and depression) were classified as mild and transient, and none required discontinuation of therapy (45).

Additional uncontrolled retrospective studies of propranolol usage in children with portal hypertension have been reported from Turkey. Seven of 45 children (15.6\%) and one of 10 children $(10 \%)$ with cirrhosis, who were not screened for varices, suffered upper gastrointestinal hemorrhage while receiving propranolol for primary prophylaxis during a median five years of follow-up in two studies from different Turkish centres $(46,47)$. Bleeding was less common in children with Child's class A cirrhosis (7.1\%) than in those with Child's class B and C combined (29.4\%) (46). The incidence of adverse effects was not reported.

Overall, the proportion of children that bled in these studies ranged from $2 \%$ to $11 \%$ per year of follow-up; no data from untreated control groups are provided (Table 1). In the studies of the natural history of portal hypertension in children that are summarized above, between $2 \%$ and $9 \%$ of children who 
did not receive prophylactic treatment suffered gastrointestinal hemorrhage during each year of follow-up. The efficacy of nonselective beta-blockers for the prevention of variceal bleeding in children, therefore, remains unclear, and the adverse event profile associated with this indication has yet to be adequately defined.

\section{POTENTIAL FOR HARM: REPORTED AND THEORETICAL RISKS OF BETA-BLOCKERS IN CHILDREN WITH PORTAL HYPERTENSION}

Children who receive nonselective beta-blockers may develop adverse effects, including bradycardia, heart failure, hypotension, conduction disorders, bronchospasm and hypoglycemia following fasting. However, these drugs are generally well tolerated; no clinically significant adverse events were reported in nine randomized controlled trials that included 309 children of whom 188 received propranolol for indications other than the prevention of variceal hemorrhage (48-56). Although there is no excess mortality among adults who bleed while receiving prophylaxis (29-40), young children respond differently to shock by relying more heavily on tachycardia due to their relatively fixed stroke volume (57). There is an important theoretical concern that, by limiting tachycardia, nonselective beta-blockers may impair tolerance of hypovolemia and worsen the outcome from variceal hemorrhage. There appear to be no reports that suggest increased morbidity or mortality following hemorrhage in children receiving appropriate therapeutic doses of nonselective beta-blockers, although the large controlled studies required to show such an effect have not been undertaken.

\section{HOW MUCH BETA-BLOCKER?}

If beta-blockers are to be used in children with portal hypertension, an effective and safe dosing regimen must be chosen. Heart rate is the most commonly used clinical end point for dosage regulation of beta-blockers in the prevention of variceal hemorrhage in adults. In most studies, the beta-blocker dose is adjusted until the heart rate is reduced to $75 \%$ of its baseline value, an arbitrary threshold chosen by Lebrec et al (27) in their original study. However, there is only a weak correlation between the effects of nonselective beta blockade on heart rate and portal hemodynamics, and variceal hemorrhage occurs in some cirrhotic adults taking beta-blockers in spite of an adequate heart rate response $(44,58,59)$. The routine use of HVPG measurements improves the prediction of response to beta-blocker therapy; a decline in HVPG to less than $12 \mathrm{mmHg}$, or by more than $20 \%$ of its baseline value, predicts a significantly lower risk of hemorrhage (0\% to $7 \%$ incidence) compared with patients who fail to achieve this reduction in HVPG (33\% to $41 \%$ incidence) (60-62). The place for routine clinical use of this relatively invasive but reportedly safe test is the subject of much debate and has yet to be tested in prospective trials (63-66).

While such studies are awaited, common clinical practice among adult hepatologists is to prescribe enough beta-blocker to reduce the heart rate to $75 \%$ of its baseline value. The reported experience of propranolol usage in children with portal hypertension follows a similar strategy, with most children requiring between $1 \mathrm{mg} / \mathrm{kg} / \mathrm{day}$ and $2 \mathrm{mg} / \mathrm{kg} /$ day to achieve the required reduction in heart rate; the risk of bleeding is possibly greater in those receiving less than $1 \mathrm{mg} / \mathrm{kg} /$ day (45).
Unfortunately, there are no pediatric data to describe the splanchnic hemodynamic response to beta blockade or the optimum dosage schedule that gives maximum efficacy (in reducing hemorrhage episodes) and minimum risk (especially impaired tolerance of shock).

\section{THERAPEUTIC OPTIONS FOR PROPHYLAXIS OF VARICEAL BLEEDING IN CHILDREN}

Endoscopic variceal ligation (EVL) provides an alternative approach to the prevention of variceal bleeding that avoids the need for long-term medication, is often suitable for patients with side effects or contraindications to beta-blockers and is at least as effective as nonselective beta-blockers in cirrhotic adults (67-76).

The evidence supporting endoscopic treatment of varices in children is more limited, although many pediatric gastroenterologists are willing to use this approach for primary prophylaxis (9). The only randomized controlled trial of primary prophylaxis of variceal hemorrhage in children studied the effect of endoscopic injection sclerotherapy (EIS) in 100 children of median age 4.3 years in Brazil (2). Most of the children had biliary atresia or another parenchymal liver disease, while nine had portal vein thrombosis. Statistically significant differences were shown between the EIS group and control group (who received no active treatment) in the all-cause gastrointestinal hemorrhage rate ( $24 \%$ versus $48 \%$, respectively) and the variceal hemorrhage rate (6\% versus $42 \%$, respectively) (2). Mortality rates were similar. The study excluded children who had the largest (grade 4) varices, and set no minimum requirement for variceal size, but the hemorrhage rate in the control group was still greater than $40 \%$. The report does not provide details of the method for selection of patients for inclusion in the study or of the timing and method of random assignment, including the process to avoid allocation bias. The interpretation of this study and the application of its results to clinical practice are, therefore, difficult.

EIS proved ineffective for primary prophylaxis in adults and has been largely replaced by EVL. Several uncontrolled case series of EVL in children suggest that it is safe, although there is little experience of its use for primary prophylaxis $(77-80)$ (Table 1). In one series of 31 children with varices who underwent EVL, there were no episodes of variceal hemorrhage and only one incidence of bleeding from portal gastropathy, suggesting that this therapy may offer effective prevention for children with both intrahepatic and prehepatic portal hypertension (78).

As with the pediatric beta-blocker studies, the lack of control groups means that there are inadequate data to base any recommendation concerning the use of an endoscopic approach to primary prophylaxis of variceal hemorrhage in children. For adults, the relative efficacy and practicality of different pharmacological, endoscopic or combined approaches to prevention of hemorrhage is vigorously debated (81-83). However, the use of nonselective beta-blockers is more cost effective than EVL $(84,85)$ and, therefore, beta-blockers remain the most widely recommended first-line prophylaxis for adult patients with varices that are at risk of bleeding $(64,86-89)$.

\section{INDIVIDUAL PATIENT CHARACTERISTICS}

It is likely that postpubertal teenagers with portal hypertension respond to beta-blockers and bleeding like adults, whereas the 
theoretical concerns about adverse outcomes from hemorrhage while receiving beta-blockers apply primarily to infants and younger children. Age may, therefore, be an important factor in the decision to prescribe beta-blockers.

Children and families differ in their perception and management of anxiety and uncertainty. Some accept endoscopic screening for varices without hesitation and are reassured by documentation of the absence of esophageal varices or are encouraged to make clear emergency action plans if large varices are identified, as well as make more informed decisions about such things as vacation travel or relocation to remote areas. Some may prefer pharmacological prophylaxis to a series of EVL procedures with its attendant need in children for general anesthesia.

In making a decision about a treatment plan for which the evidence is unclear, families will differ in their understanding and interpretation of the information provided to them, in their acceptance of risk and their perception of possible benefits. Most clinicians recognize that these differences among families form an important part of treatment decisions and accept that doctors do not always know what is best for each individual child that they treat; their practice has, therefore,

\section{REFERENCES}

1. Lykavieris P, Gauthier F, Hadchouel P, Duche M, Bernard O. Risk of gastrointestinal bleeding during adolescence and early adulthood in children with portal vein obstruction. J Pediatr 2000;136:805-8.

2. Goncalves ME, Cardoso SR, Maksoud JG. Prophylactic sclerotherapy in children with esophageal varices: Long-term results of a controlled prospective randomized trial. J Pediatr Surg 2000;35:401-5.

3. Miga D, Sokol RJ, Mackenzie T, Narkewicz MR, Smith D, Karrer FM. Survival after first esophageal variceal hemorrhage in patients with biliary atresia. J Pediatr 2001;139:291-6.

4. van Heurn LW, Saing H, Tam PK. Portoenterostomy for biliary atresia: Long-term survival and prognosis after esophageal variceal bleeding. J Pediatr Surg 2004;39:6-9.

5. Kobayashi A, Itabashi F, Ohbe Y. Long-term prognosis in biliary atresia after hepatic portoenterostomy: Analysis of 35 patients who survived beyond 5 years of age. J Pediatr 1984;105:243-6.

6. Toyosaka A, Okamoto E, Okasora T, Nose K, Tomimoto Y. Outcome of 21 patients with biliary atresia living more than 10 years. J Pediatr Surg 1993;28:1498-501.

7. Mitra SK, Kumar V, Datta DV, et al. Extrahepatic portal hypertension: a review of 70 cases. J Pediatr Surg 1978;13:51-7.

8. Webb LJ, Sherlock S. The aetiology, presentation and natural history of extra-hepatic portal venous obstruction. Q J Med 1979;48:627-39.

9. Shneider BL. Approaches to the management of pediatric portal hypertension: Results of an informal survey. In: Groszmann RJ, Bosch J, eds. Portal Hypertension in the 21st Century. Dordrecht, The Netherlands: Kluwer Academic Publishers, 2004:167-72.

10. Schreiber RA. Propranolol and portal hypertension: Should kids be on the block? J Pediatr Gastroenterol Nutr 1999;29:10-1.

11. Wanless IR, Wong F, Blendis LM, Greig P, Heathcote EJ, Levy G. Hepatic and portal vein thrombosis in cirrhosis: Possible role in development of parenchymal extinction and portal hypertension. Hepatology 1995;21:1238-47.

12. Garcia-Pagan JC, Bosch J, Rodes J. The role of vasoactive mediators in portal hypertension. Semin Gastrointest Dis 1995;6:140-7.

13. Ballet F, Chretien Y, Rey C, Poupon R. Differential response of normal and cirrhotic liver to vasoactive agents. A study in the isolated perfused rat liver. J Pharmacol Exp Ther 1988;244:283-9.

14. Farzaneh-Far R, Moore K. Cysteinyl-leukotrienes and the liver. Prostaglandins Other Lipid Mediat 2003;72:35-50.

15. Kaneda K, Ekataksin W, Sogawa M, Matsumura A, Cho A, Kawada N. Endothelin-1-induced vasoconstriction causes a significant increase in portal pressure of rat liver: localized constrictive effect on the distal segment of preterminal portal venules as revealed by light and electron microscopy and serial reconstruction. Hepatology 1998;27:735-47. moved toward fuller discussion with families and facilitation of a greater role for the child and family in the decision-making process (90).

\section{SUMMARY}

Nonselective beta-blocker therapy reduces the incidence of first variceal hemorrhage in cirrhotic adults with large varices and is more cost-effective than EVL. Unfortunately, 25 years after the dawn of pharmacological prevention of variceal hemorrhage in adults, there remains a pressing need for randomized controlled studies in children at risk of fatal variceal hemorrhage. Meanwhile, pediatric gastroenterologists who wish to prescribe nonselective beta-blockers for primary prophylaxis must be mindful of the lack of pediatric evidence and the potential age-related adverse effects. They should carefully consider each patient's circumstances and discuss the situation fully with the patient and parents, whose opinions of what is best should be carefully heard.

ACKNOWLEDGEMENTS: The author thanks Dr Yaron Avitzur for his comments on the manuscript.

16. Kawada N, Tran-Thi TA, Klein H, Decker K. The contraction of hepatic stellate (Ito) cells stimulated with vasoactive substances. Possible involvement of endothelin 1 and nitric oxide in the regulation of the sinusoidal tonus. Eur J Biochem 1993;213:815-23.

17. Benoit JN, Zimmerman B, Premen AJ, Go VL, Granger DN. Role of glucagon in splanchnic hyperemia of chronic portal hypertension. Am J Physiol 1986;251:G674-7.

18. Wiest R, Groszmann RJ. The paradox of nitric oxide in cirrhosis and portal hypertension: Too much, not enough. Hepatology 2002;35:478-91.

19. Bosch J, D’Amico G, Garcia-Pagan JC. Portal hypertension. In: Schiff ER, Sorrell MF, Maddrey WC, eds. Schiff's Diseases of the Liver, 9th edn. Philadelphia: Lippincott Williams \& Wilkins, 2003:429-85.

20. Groszmann RJ, Wongcharatrawee S. The hepatic venous pressure gradient: Anything worth doing should be done right. Hepatology 2004:39:280-2.

21. Garcia-Tsao G, Groszmann RJ, Fisher RL, Conn HO, Atterbury CE, Glickman M. Portal pressure, presence of gastroesophageal varices and variceal bleeding. Hepatology 1985;5:419-24 .

22. Fernandez M, Vizzutti F, Garcia-Pagan JC, Rodes J, Bosch J. AntiVEGF receptor-2 monoclonal antibody prevents portal-systemic collateral vessel formation in portal hypertensive mice. Gastroenterology 2004;126:886-94.

23. Merkel C, Zoli M, Siringo S, et al. Prognostic indicators of risk for first variceal bleeding in cirrhosis: a multicenter study in 711 patients to validate and improve the North Italian Endoscopic Club (NIEC) index. Am J Gastroenterol 2000;95:2915-20.

24. Lebrec D. Pharmacological treatment of portal hypertension: Hemodynamic effects and prevention of bleeding. Pharmacol Ther 1994;61:65-107.

25. Westaby D, Bihari DJ, Gimson AE, Crossley IR, Williams R. Selective and non-selective beta receptor blockade in the reduction of portal pressure in patients with cirrhosis and portal hypertension. Gut 1984;25:121-4

26. Lebrec D, Hillon P, Munoz C, Goldfarb G, Nouel O, Benhamou JP. The effect of propranolol on portal hypertension in patients with cirrhosis: A hemodynamic study. Hepatology 1982;2:523-7.

27. Lebrec D, Nouel O, Corbic M, Benhamou JP. Propranolol a medical treatment for portal hypertension? Lancet 1980;2:180-2.

28. Lebrec D, Poynard T, Bernuau J, et al. A randomized controlled study of propranolol for prevention of recurrent gastrointestinal bleeding in patients with cirrhosis: A final report. Hepatology 1984;4:355-8. 
29. Pascal JP, Cales P. Propranolol in the prevention of first upper gastrointestinal tract hemorrhage in patients with cirrhosis of the liver and esophageal varices. N Engl J Med 1987;317:856-61.

30. Lebrec D, Poynard T, Capron JP, et al. Nadolol for prophylaxis of gastrointestinal bleeding in patients with cirrhosis. A randomized trial. J Hepatol 1988;7:118-25.

31. Ideo G, Bellati G, Fesce E, Grimoldi D. Nadolol can prevent the first gastrointestinal bleeding in cirrhotics: A prospective, randomized study. Hepatology 1988;8:6-9.

32. Propranolol prevents first gastrointestinal bleeding in non-ascitic cirrhotic patients. Final report of a multicenter randomized trial. The Italian multicenter project for propranolol in prevention of bleeding. J Hepatol 1989;9:75-83.

33. Andreani T, Poupon RE, Balkau BJ, et al. Preventive therapy of first gastrointestinal bleeding in patients with cirrhosis: Results of a controlled trial comparing propranolol, endoscopic sclerotherapy and placebo. Hepatology 1990;12:1413-9.

34. Colman J, Jones P, Finch C, Dudley F. Propranolol in the prevention of variceal haemorrhage in alcoholic cirrhotic patients. Hepatology $1990 ; 12: 851$

35. Conn HO, Grace ND, Bosch J, et al. Propranolol in the prevention of the first hemorrhage from esophagogastric varices: A multicenter randomized clinical trial. The Boston-New Haven-Barcelona portal hypertension study group. Hepatology 1991;13:902-12.

36. Prophylaxis of first hemorrhage from esophageal varices by sclerotherapy, propranolol or both in cirrhotic patients: A randomized multicenter trial. The PROVA study group. Hepatology 1991;14:1016-24.

37. Strauss E, de Sa MF, Albano A, Lacet CMC, Leiti MO, Maffei RA Jr. A randomised controlled trial for the prevention of the first upper gastro- intestinal bleeding due to portal hypertension in cirrhosis: Sclerotherapy or propranolol versus control groups. Hepatology 1988;8:1395. (Abst)

38. Pagliaro L, D'Amico G, Sorensen TI, et al. Prevention of first bleeding in cirrhosis. A meta-analysis of randomized trials of nonsurgical treatment. Ann Intern Med 1992;117:59-70.

39. Hayes PC, Davis JM, Lewis JA, Bouchier IA. Meta-analysis of value of propranolol in prevention of variceal haemorrhage. Lancet 1990;336:153-6. (Erratum in 1990;336:324).

40. D'Amico G, Pagliaro L, Bosch J. The treatment of portal hypertension: A meta-analytic review. Hepatology 1995;22:332-54.

41. Steinbrook R. Testing medications in children. N Engl J Med 2002;347:1462-70.

42. Caldwell PH, Murphy SB, Butow PN, Craig JC. Clinical trials in children. Lancet 2004;364:803-11.

43. Poynard T, Cales P, Pasta L, et al. Beta-adrenergic-antagonist drugs in the prevention of gastrointestinal bleeding in patients with cirrhosis and esophageal varices. An analysis of data and prognostic factors in 589 patients from four randomized clinical trials. FrancoItalian multicenter study group. N Engl J Med 1991;324:1532-8.

44. Ozsoylu S, Kocak N, Yuce A. Propranolol therapy for portal hypertension in children. J Pediatr 1985;106:317-21.

45. Shashidhar H, Langhans N, Grand RJ. Propranolol in prevention of portal hypertensive hemorrhage in children: A pilot study. J Pediatr Gastroenterol Nutr 1999;29:12-7.

46. Ozsoylu S, Kocak N, Demir H, Yuce A, Gurakan F, Ozen H. Propranolol for primary and secondary prophylaxis of variceal bleeding in children with cirrhosis. Turk J Pediatr 2000;42:31-3.

47. Erkan T, Cullu F, Kutlu T, et al. Management of portal hypertension in children: A retrospective study with long-term follow-up. Acta Gastroenterol Belg 2003;66:213-7.

48. Aarsland A, Chinkes D, Wolfe RR, et al. Beta-blockade lowers peripheral lipolysis in burn patients receiving growth hormone. Rate of hepatic very low density lipoprotein triglyceride secretion remains unchanged. Ann Surg 1996;223:777-87.

49. Olness K, MacDonald JT, Uden DL. Comparison of self-hypnosis and propranolol in the treatment of juvenile classic migraine. Pediatrics 1987;79:593-7.

50. Buchhorn R, Hulpke-Wette M, Hilgers R, Bartmus D, Wessel A, Bursch J. Propranolol treatment of congestive heart failure in infants with congenital heart disease: The CHF-PRO-INFANT trial. Congestive heart failure in infants treated with propanol. Int J Cardiol 2001;79:167-73

51. Gidding SS, Rocchini AP, Beekman R, et al. Therapeutic effect of propranolol on paradoxical hypertension after repair of coarctation of the aorta. N Engl J Med 1985;312:1224-8.
52. Leenen FH, Balfe JA, Pelech AN, Barker GA, Balfe JW, Olley PM. Postoperative hypertension after repair of coarctation of aorta in children: Protective effect of propranolol? Am Heart J 1987;113:1164-73.

53. Hart DW, Wolf SE, Chinkes DL, Lal SO, Ramzy PI, Herndon DN. Beta-blockade and growth hormone after burn. Ann Surg 2002;236:450-6.

54. Herndon DN, Hart DW, Wolf SE, Chinkes DL, Wolfe RR. Reversal of catabolism by beta-blockade after severe burns. N Engl J Med 2001;345:1223-9.

55. Herndon DN, Dasu MR, Wolfe RR, Barrow RE. Gene expression profiles and protein balance in skeletal muscle of burned children after beta-adrenergic blockade. Am J Physiol Endocrinol Metab 2003;285:E783-9.

56. Berenson GS, Shear CL, Chiang YK, Webber LS, Voors AW. Combined low-dose medication and primary intervention over a 30-month period for sustained high blood pressure in childhood. Am J Med Sci 1990;299:79-86.

57. Witte MK, Hill JH, Blumer JL. Shock in the pediatric patient. Adv Pediatr 1987;34:139-73

58. Bosch J, Masti R, Kravetz D, et al. Effects of propranolol on azygos venous blood flow and hepatic and systemic hemodynamics in cirrhosis. Hepatology 1984;4:1200-5.

59. Garcia-Tsao G, Grace ND, Groszmann RJ, et al. Short-term effects of propranolol on portal venous pressure. Hepatology 1986;6:101-6.

60. Bureau C, Peron JM, Alric L, et al. "A la carte" treatment of portal hypertension: Adapting medical therapy to hemodynamic response for the prevention of bleeding. Hepatology 2002;36:1361-6.

61. Groszmann RJ, Bosch J, Grace ND, et al. Hemodynamic events in a prospective randomized trial of propranolol versus placebo in the prevention of a first variceal hemorrhage. Gastroenterology 1990;99:1401-7.

62. Merkel C, Bolognesi M, Sacerdoti D, et al. The hemodynamic response to medical treatment of portal hypertension as a predictor of clinical effectiveness in the primary prophylaxis of variceal bleeding in cirrhosis. Hepatology 2000;32:930-4.

63. Thalheimer U, Mela M, Patch D, Burroughs AK. Targeting portal pressure measurements: A critical reappraisal. Hepatology 2004:39:286-90.

64. Bosch J, Abraldes JG, Groszmann R. Current management of portal hypertension. J Hepatol 2003;38(Suppl 1):S54-S68.

65. Boyer TD. Changing clinical practice with measurements of portal pressure. Hepatology 2004:39:283-5.

66. Targownik LE, Spiegel BM, Dulai GS, Karsan HA, Gralnek IM. The cost-effectiveness of hepatic venous pressure gradient monitoring in the prevention of recurrent variceal hemorrhage. Am J Gastroenterol 2004;99:1306-15.

67. Chen CY, Sheu MZ, Su SY. Prophylactic endoscopic variceal ligation (EVL) with multiple band ligator for oesophageal varices. Gastroenterology 1998;114:A1224. (Abst)

68. Sarin SK, Lamba GS, Kumar M, Misra A, Murthy NS. Comparison of endoscopic ligation and propranolol for the primary prevention of variceal bleeding. N Engl J Med 1999;340:988-93.

69. De BK, Ghoshal UC, Das T, Santra A, Biswas PK. Endoscopic variceal ligation for primary prophylaxis of oesophageal variceal bleed: Preliminary report of a randomized controlled trial. J Gastroenterol Hepatol 1999;14:220-4.

70. Jutabha R, Jensen DM, Martin P, et al. Initial report of a randomized, prospective study of prophylactic propranolol compared to rubber band ligation for prevention of first variceal hemorrhage in cirrhotics with large esophageal varices. Gastroenterology 2000;118:A212. (Abst)

71. de la Mora JG, Farca-Belsaguy AA, Uribe M, de Hoyos-Garza A. Ligation vs. propranolol for primary prophylaxis of variceal bleeding using multiple band ligator and objective measurements of treatment adequacy: Preliminary results. Gastroenterology 2000;118:A1434. (Abst)

72. Lui HF, Stanley AJ, Forrest EH, et al. Primary prophylaxis of variceal hemorrhage: A randomized controlled trial comparing band ligation, propranolol, and isosorbide mononitrate. Gastroenterology 2002:123:735-44.

73. Lo GH, Chen WC, Chen MH, et al. Endoscopic ligation vs. nadolol in the prevention of first variceal bleeding in patients with cirrhosis. Gastrointest Endosc 2004;59:333-8. 
74. Schepke M, Kleber G, Nurnberg D, et al. Ligation versus propranolol for the primary prophylaxis of variceal bleeding in cirrhosis. Hepatology 2004;40:65-72.

75. Imperiale TF, Chalasani N. A meta-analysis of endoscopic variceal ligation for primary prophylaxis of esophageal variceal bleeding. Hepatology 2001;33:802-7.

76. Khuroo MS, Khuroo NS, Farahat KL, Khuroo YS, Sofi AA, Dahab ST. Meta-analysis: Endoscopic variceal ligation for primary prophylaxis of oesophageal variceal bleeding. Aliment Pharmacol Ther 2005;21:347-61.

77. Cano I, Urruzuno P, Medina E, et al. Treatment of esophageal varices by endoscopic ligation in children. Eur J Pediatr Surg 1995;5:299-302.

78. Celinska-Cedro D, Teisseyre M, Woynarowski M, Socha P, Socha J, Ryzko J. Endoscopic ligation of esophageal varices for prophylaxis of first bleeding in children and adolescents with portal hypertension: Preliminary results of a prospective study. J Pediatr Surg 2003;38:1008-11.

79. Reinoso MA, Sharp HL, Rank J. Endoscopic variceal ligation in pediatric patients with portal hypertension secondary to liver cirrhosis. Gastrointest Endosc 1997;46:244-6.

80. Sasaki T, Hasegawa T, Nakajima K, et al. Endoscopic variceal ligation in the management of gastroesophageal varices in postoperative biliary atresia. J Pediatr Surg 1998;33:1628-32.

81. Sharara AI, Rockey DC. Therapy for primary prophylaxis of varices: And, the winner is...? Hepatology 2003;37:473-5.

82. Burroughs AK, Patch D. Primary prevention of bleeding from esophageal varices. N Engl J Med 1999;340:1033-5.

83. Garcia-Pagan JC. Non-selective beta-blockers in the prevention of first variceal bleeding. Is there any definite alternative? J Hepatol 2002;37:393-5.
84. Spiegel BM, Targownik L, Dulai GS, Karsan HA, Gralnek IM. Endoscopic screening for esophageal varices in cirrhosis: Is it ever cost effective? Hepatology 2003;37:366-77.

85. Saab S, DeRosa V, Nieto J, Durazo F, Han S, Roth B. Costs and clinical outcomes of primary prophylaxis of variceal bleeding in patients with hepatic cirrhosis: A decision analytic model. Am J Gastroenterol 2003;98:763-70.

86. de Franchis R, Pascal JP, Ancona E, et al. Definitions, methodology and therapeutic strategies in portal hypertension. A consensus development workshop, Baveno, Lake Maggiore, Italy, April 5 and 6, 1990. J Hepatol 1992;15:256-61.

87. Jalan R, Hayes PC. UK guidelines on the management of variceal haemorrhage in cirrhotic patients. British society of gastroenterology. Gut 2000;46(Suppl 3-4):III1-III15.

88. Grace ND. Diagnosis and treatment of gastrointestinal bleeding secondary to portal hypertension. American college of gastroenterology practice parameters committee. Am J Gastroenterol 1997;92:1081-91.

89. Boyer TD. Primary prophylaxis for variceal bleeding: Are we there yet? Gastroenterology 2005;128:1120-2.

90. Veatch RM. Doctor does not know best: Why in the new century physicians must stop trying to benefit patients. J Med Philos 2000;25:701-21.

91. Howard ER, Stringer MD, Mowat AP. Assessment of injection sclerotherapy in the management of 152 children with oesophageal varices. Br J Surg 1988;75:404-8.

92. Maksoud JG, Goncalves ME, Porta G, Miura I, Velhote MC. The endoscopic and surgical management of portal hypertension in children: Analysis of 123 cases. J Pediatr Surg 1991;26:178-81. 


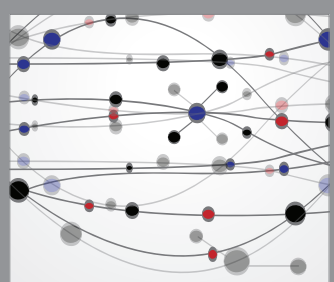

The Scientific World Journal
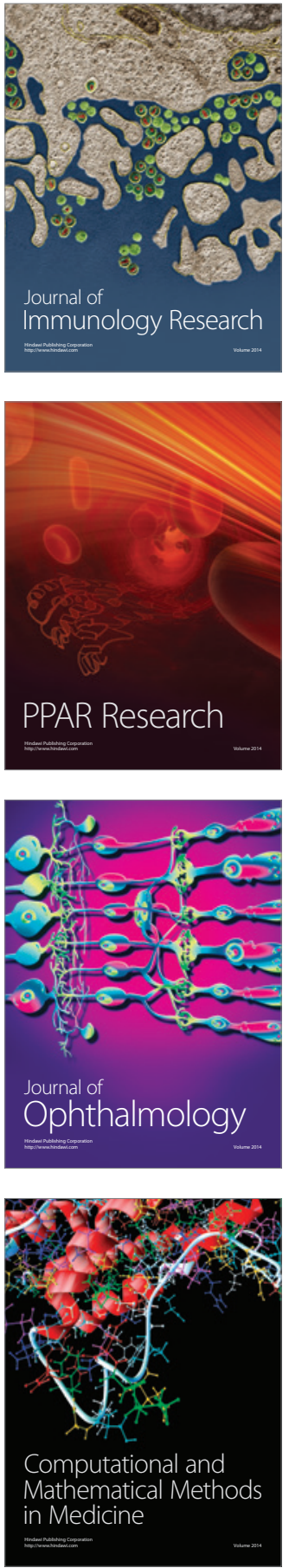

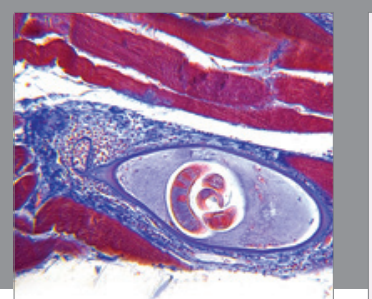

Gastroenterology Research and Practice

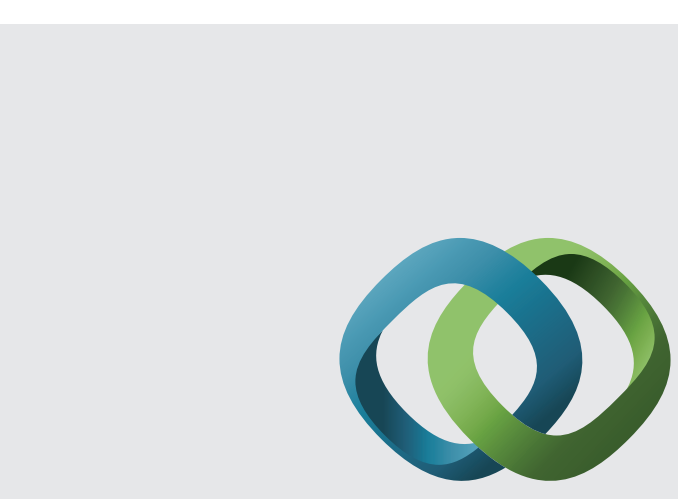

\section{Hindawi}

Submit your manuscripts at

http://www.hindawi.com
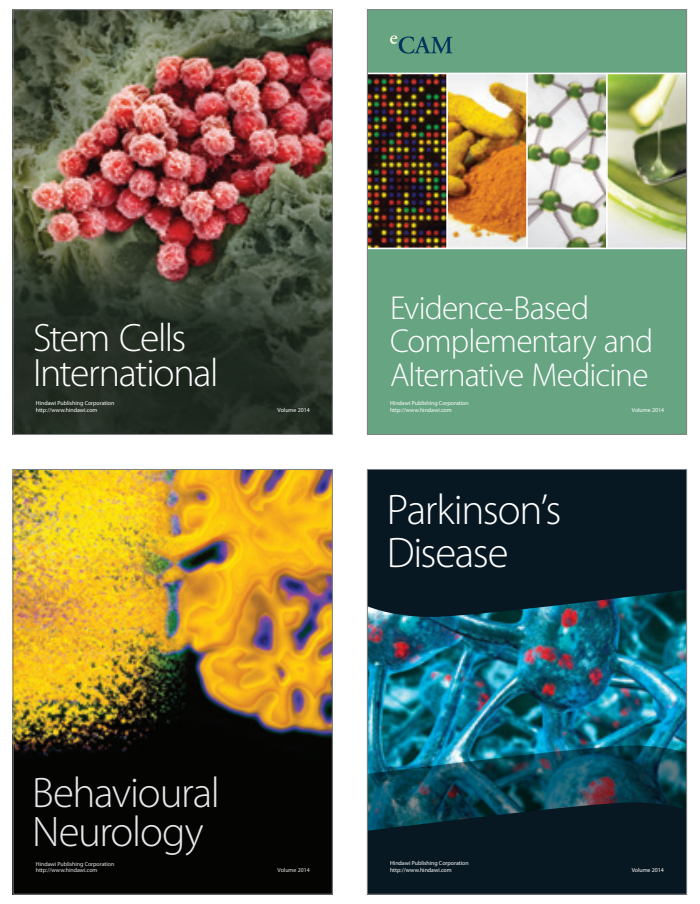
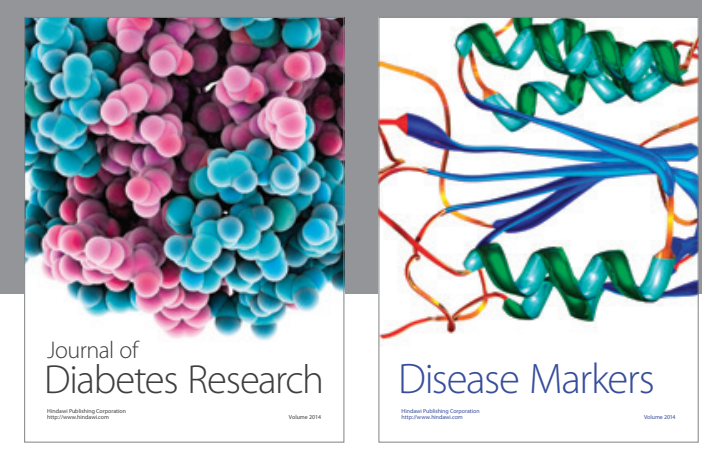

Disease Markers
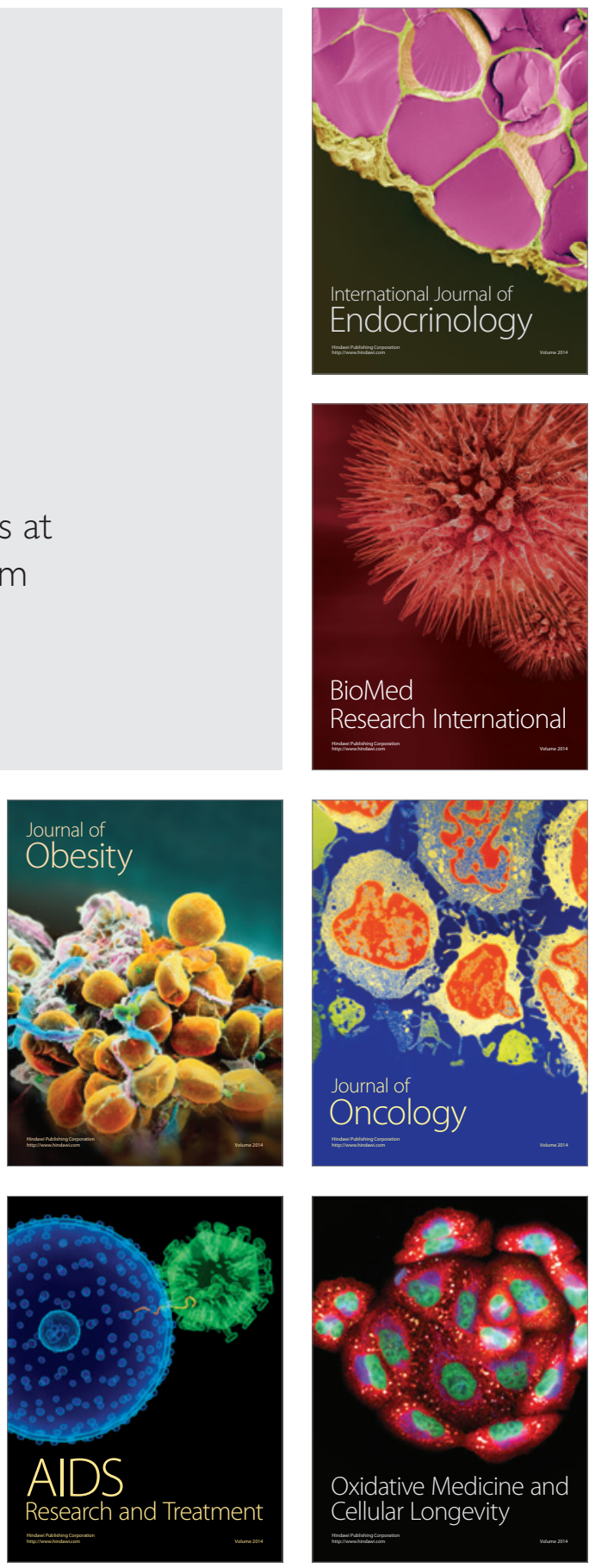